\title{
Nitriding of a High Entropy FeNiMnAlCr Alloy
}

Fanling Meng and Ian Baker

14 Engineering Dr., Dartmouth College, Hanover, NH 03755, U.S.A. telephone number: 603-646-2184; email: Ian.Baker@dartmouth.edu

\begin{abstract}
The as-cast, two-phase, f.c.c. + B2, lamellar-structured, high-entropy alloy $\mathrm{Fe}_{28.2} \mathrm{Ni}_{18.8} \mathrm{Mn}_{32.9} \mathrm{Al}_{14.1} \mathrm{Cr}_{6}$ was annealed in pure nitrogen at either $800^{\circ} \mathrm{C}$ or $1000^{\circ} \mathrm{C}$ for $100 \mathrm{~h}$ in order to harden the surface by nitridation. Similar nitriding treatments were performed on a comparably-structured, four-component alloy $\mathrm{Fe}_{30} \mathrm{Ni}_{20} \mathrm{Mn}_{35} \mathrm{Al}_{15}$ for comparison. Scanning electron microscopy and energy dispersive X-ray spectroscopy were used to analyze the resulting microstructures and phase compositions. AIN formation near the surface completely depleted the matrix of $\mathrm{Al}$ resulting in a f.c.c. matrix containing AlN particles, while a two-phase lamellae structure remained in the center of the specimens. Nevertheless, the AlN-containing region exhibited a higher hardness than the AlN-free area. Interestingly, the presence of Cr led to much more rapid diffusion of nitrogen into the material
\end{abstract}

Keywords: High entropy alloy, nitriding, microstructure, hardness 


\section{Introduction}

A variety of methods can be used to harden the surface of metals, ranging from flame hardening and weld hardening processes to ion beam processes and new surface coating methods [1]. Nitriding is one such process in which the metal is heated to allow nitrogen to diffuse into the surface, thus producing a case-hardened surface by the precipitation of very small particles of a the nitride [1-3]. The hardness of the resulting surface layer depends on the type, size and distribution of nitride, which is affected by the type of metal being nitrided, the nitriding temperature, the cooling rate from the nitriding temperature and any annealing after the process [2]. Nitriding is often performed at intermediate temperatures in an ammonia atmosphere [1, 3, 4]. Nitriding is performed mostly on low-carbon, low-alloy steels [4, 5]. However, nitriding is also sometimes used on medium and high-carbon steels, titanium alloys and aluminum alloys [69]. Typical applications that use case-hardened steel produced by nitriding include gears, crankshafts, camshafts, valve parts, and various dies for extrusion or die casting [4]. Very often, the above applications require high wear resistance and gas nitriding is one of the most efficient hardening methods to improve the wear resistance, especially in the cases of complicated shape elements $[5,6]$.

$\mathrm{Fe}_{30} \mathrm{Ni}_{20} \mathrm{Mn}_{35} \mathrm{Al}_{15}$ is a recently discovered two-phase alloy, consisting of alternating (Fe, Mn)-rich f.c.c. and (Ni, Al)-rich B2 lamellae [10]. Drop-cast $\mathrm{Fe}_{30} \mathrm{Ni}_{20} \mathrm{Mn}_{35} \mathrm{Al}_{15}$ tensile tested at a strain rate of $3 \times 10^{-3} \mathrm{~s}^{-1}$ in air exhibits a yield strength of $600 \mathrm{MPa}$, a fracture strength of $850 \mathrm{MPa}$ and a strain to failure of $\sim 11 \%$ [11]. Unfortunately, this alloy shows $<1 \%$ elongation when strained in air at a strain rate of $3 \times 10^{-6} \mathrm{~s}^{-1}$. This environmental embrittlement is also manifested in pin-on-disc wear tests, where tests performed in air show much more rapid wear than tests performed under argon $[12,13]$. The addition of 6 at. \% chromium to produce the high entropy alloy (HEA) $\mathrm{Fe}_{28.2} \mathrm{Ni}_{18.8} \mathrm{Mn}_{32.9} \mathrm{Al}_{14.1} \mathrm{Cr}_{6}$ not only alleviated this environmental embrittlement, but also increased the elongation to failure to 18\%, although at the expense of a slight reduction in yield strength $[14,15]$.

HEAs are single phase or multiphase and contain 5-35 at. \% of five or more elements [16]. They are of interest for a variety of industrial applications because of their unusual properties [17-21]. A key feature is the sluggish diffusion observed in these materials [22]. This is of particular interest for high temperature applications since it implies good thermal stability of the phases present [23] and good high temperature mechanical properties, which are typically 
controlled by the diffusion kinetics [24]. Some HEAs can show excellent mechanical properties at cryogenic temperatures with both yield strength, work-hardening rate and ductility increasing with decreasing temperature to $77 \mathrm{~K}$ [25-26]. In fact, one such f.c.c. HEA, CrMnFeCoNi, has been shown to exhibit the highest recorded fracture toughness of $>200 \mathrm{MPa} . \mathrm{m}^{1 / 2}$ at temperatures from $77 \mathrm{~K}$ to room temperature [27].

Because FeNiMnAlCr alloys contain the nitride-forming elements $\mathrm{Al}$ and $\mathrm{Cr}$, it may be possible to harden the surface of $\mathrm{Fe}_{28.2} \mathrm{Ni}_{18.8} \mathrm{Mn}_{32.9} \mathrm{Al}_{14.1} \mathrm{Cr}_{6}$ by nitriding. Thus, in this paper we describe the production, microstructures and hardness of a hardened surface layer in the HEA alloy $\mathrm{Fe}_{28.2} \mathrm{Ni}_{18.8} \mathrm{Mn}_{32.9} \mathrm{Al}_{14.1} \mathrm{Cr}_{6}$ after nitriding in a pure nitrogen atmosphere at either $800^{\circ} \mathrm{C}$ or $1000^{\circ} \mathrm{C}$. We also examined the effects of nitriding the base alloy $\mathrm{Fe}_{30} \mathrm{Ni}_{20} \mathrm{Mn}_{35} \mathrm{Al}_{15}$ to understand how the $\mathrm{Cr}$ addition affects the kinetics of nitriding, the microstructure and the resulting mechanical behavior.

\section{Experimental}

$60 \mathrm{~g}$ ingots of alloy with nominal atomic compositions of $\mathrm{Fe}_{28.2} \mathrm{Ni}_{18.8} \mathrm{Mn}_{32.9} \mathrm{Al}_{14.1} \mathrm{Cr}_{6}$ and $\mathrm{Fe}_{30} \mathrm{Ni}_{20} \mathrm{Mn}_{35} \mathrm{Al}_{15}$ were produced from pieces of $99.8 \% \mathrm{Fe}$, 99.95\% Ni, 99.8\% $\mathrm{Mn}, 99.8 \% \mathrm{Al}$ and 99.8\% Cr. An additional 5 wt. \% Mn was added to compensate for the loss of manganese due to evaporation during casting. After being weighed, the pieces were placed in a water-chilled copper crucible and arc-melted under an argon atmosphere. Ingots were flipped and re-melted twice after the initial melting to ensure homogeneous mixing.

A Rigaku D/Max 2000 diffractometer with $\mathrm{Cu} \mathrm{K} \alpha$ radiation operated at $40 \mathrm{kV}$ and $300 \mathrm{~mA}$ was used to perform phase identification. Specimens were polished to a mirror finish. Measurements were performed by step scanning $2 \theta$ from $20^{\circ}$ to $120^{\circ}$ with a $0.02^{\circ}$ step size. A count time of $1 \mathrm{~s}$ per step was used, giving a total scan time of $\sim 1.5 \mathrm{~h}$.

Specimen cut from the ingots were annealed at either $800^{\circ} \mathrm{C}$ or $1000^{\circ} \mathrm{C}$ for $100 \mathrm{~h}$ in a pure nitrogen atmosphere in order to nitride the surface. Specimens, cut from the annealed ingots, were mounted in phenolic resin and polished, using increasingly fine grades of silicon carbide papers followed by $0.3 \mu \mathrm{m}$ alumina powder, to a mirror finish. The surfaces were etched using $4 \%$ nitric acid for $\sim 5$ s followed by rinsing in water. An FEI XL-30 field emission gun (FEG) scanning electron microscope (SEM) equipped with an EDAX Li-drifted energy dispersive X- 
ray spectrometer (EDS) was used at a voltage of $15 \mathrm{kV}$ for examination of the annealed specimens.

The Vickers hardness of the specimens was measured using a TIME TH-713 Microhardness Tester. All tests were performed at a load of $200 \mathrm{~g}(1.96 \mathrm{~N})$ and a dwell time of 15s. The reported Vickers hardness values are the average of 10 measurements, and the reported error is the standard deviation.

\section{Results and Discussion}

As-cast $\mathrm{Fe}_{28.2} \mathrm{Ni}_{18.8} \mathrm{Mn}_{32.9} \mathrm{Al}_{14.1} \mathrm{Cr}_{6}$ consists of alternating lamellae $\mathrm{B} 2$ and f.c.c. phases, as shown in Figure 1(a). The width of the f.c.c. phase is $\sim 400 \mathrm{~nm}$, separated by a $200 \mathrm{~nm}$ wide B2 phase. The secondary electron (SE) image in Figure 1(b) shows that as-cast $\mathrm{Fe}_{30} \mathrm{Ni}_{20} \mathrm{Mn}_{35} \mathrm{Al}_{15}$ has a similar microstructure consisting of alternating f.c.c. and B2 phases with lamellae widths of $\sim 500 \mathrm{~nm}$ and $\sim 200 \mathrm{~nm}$, respectively. The compositions (in at. \%) of the phases in as-cast state are shown in Table 1, indicating that the f.c.c. phase is rich in Fe and Mn, while the B2 phase is rich in $\mathrm{Ni}$ and $\mathrm{Al}$.

Figure 2 shows back-scattered electrons (BSE) images of the HEA alloy $\mathrm{Fe}_{28.2} \mathrm{Ni}_{18.8} \mathrm{Mn}_{32.9} \mathrm{Al}_{14.1} \mathrm{Cr}_{6}$ and of $\mathrm{Fe}_{30} \mathrm{Ni}_{20} \mathrm{Mn}_{35} \mathrm{Al}_{15}$ after annealing in nitrogen for $100 \mathrm{~h}$ at different temperatures. Figure 2(a) shows the morphology of $\mathrm{Fe}_{28.2} \mathrm{Ni}_{18.8} \mathrm{Mn}_{32.9} \mathrm{Al}_{14.1} \mathrm{Cr}_{6}$ after annealing at $800^{\circ} \mathrm{C}$, showing local areas of AlN formation with a maximum depth of $\sim 40 \mu \mathrm{m}$. $\mathrm{Fe}_{30} \mathrm{Ni}_{20} \mathrm{Mn}_{35} \mathrm{Al}_{15}$ after annealing at $800^{\circ} \mathrm{C}$ exhibited a similar structure, with the maximum depth of the AlN layer being 20 $\mu \mathrm{m}$, see in Figure 2(c). Interestingly, all of the AlN areas are associated with cracks in external oxide layers, which allow nitrogen to penetrate into the nearsurface area of the alloy [9, 28]. Krupp et al. noted that the nitrogen attack in nickel-based alloys was strongly localized and, thereby, the penetration depth of the zones of nitride precipitation were extremely heterogeneous [9]. Figure 2(b) presents the continuous nitride layers of $\mathrm{Fe}_{28.2} \mathrm{Ni}_{18.8} \mathrm{Mn}_{32.9} \mathrm{Al}_{14.1} \mathrm{Cr}_{6}$ after annealing at $1000^{\circ} \mathrm{C}$. The thickness of the AlN layer is $\sim 1000 \mu \mathrm{m}$. The calculated diffusivity of nitrogen in $\mathrm{Fe}_{28.2} \mathrm{Ni}_{18.8} \mathrm{Mn}_{32.9} \mathrm{Al}_{14.1} \mathrm{Cr}_{6}$ at $1000^{\circ} \mathrm{C}$ is $2.8 \times$ $10^{-8} \mathrm{~cm}^{2} / \mathrm{s}$ at $1000^{\circ} \mathrm{C}$ using $\lambda=\sqrt{D t}$, where $\lambda$ is the depth of nitride layer and $\mathrm{t}$ is the nitriding time. Grabke et al. [29] showed that the diffusivity of nitrogen in Fe-Ni alloy increases with increasing Ni content. The diffusivity of nitrogen in pure iron is $1.07 \times 10^{-7} \mathrm{~cm}^{2} / \mathrm{s}$ at $1000^{\circ} \mathrm{C}$, 
while that for nitrogen in Fe-40 wt $\% \mathrm{Ni}$ is $6.6 \times 10^{-7} \mathrm{~cm}^{2} / \mathrm{s}$ at $1000^{\circ} \mathrm{C}$ [29]. As shown in Figure 2(d), a continuous AlN layer was also found in $\mathrm{Fe}_{30} \mathrm{Ni}_{20} \mathrm{Mn}_{35} \mathrm{Al}_{15}$ after annealing at $1000^{\circ} \mathrm{C}$, with a thickness of the nitride layer of $\sim 450 \mu \mathrm{m}$. The diffusivity of nitrogen in $\mathrm{Fe}_{30} \mathrm{Ni}_{20} \mathrm{Mn}_{35} \mathrm{Al}_{15}$ at $1000^{\circ} \mathrm{C}$ is $0.56 \times 10^{-8} \mathrm{~cm}^{2} / \mathrm{s}$. The total thickness of the nitride layers was greater at higher temperatures as expected since diffusion would be faster [4]. Moreover, it has been found previously that the $\mathrm{Cr}$ content of the Ni alloys strongly affected both the nitrogen solubility and the nitrogen diffusion coefficient [9]. In Ni-Cr-Ti alloys, a higher chromium content led to an increased depth of the internal precipitation of TiN [9]. Similar behavior was observed in the present study.

Figure 3(a and b) shows details of the microstructures from different areas of $\mathrm{Fe}_{28.2} \mathrm{Ni}_{18.8} \mathrm{Mn}_{32.9} \mathrm{Al}_{14.1} \mathrm{Cr}_{6}$ after annealing at $800^{\circ} \mathrm{C}$ for $100 \mathrm{~h}$ in nitrogen, with corresponding EDS data (Figure 3c and d) from dark precipitates and light matrix in the near-surface layer. In the center of the specimen the largely unchanged two-phase lamellar microstructure was present, which is the same as that of as-cast $\mathrm{Fe}_{28.2} \mathrm{Ni}_{18.8} \mathrm{Mn}_{32.9} \mathrm{Al}_{14.1} \mathrm{Cr}_{6}$ [10]. EDS results confirm that the needlelike-shaped precipitates in the near-surface region are AlN. The compositions of all the phases in the annealed materials are presented in Table 1. In the center of the specimen, the compositions of f.c.c. and B2 phases are similar to those in as-cast materials. In the AlNcontaining region, EDS results showed that less than $1 \% \mathrm{Al}$ is left. Figure 4 shows the microstructures of $\mathrm{Fe}_{30} \mathrm{Ni}_{20} \mathrm{Mn}_{35} \mathrm{Al}_{15}$ after annealing at $800^{\circ} \mathrm{C}$ for $100 \mathrm{~h}$ in nitrogen. Similar to the Cr-containing alloy, the two-phase microstructure remained largely unchanged in the center area while AlN precipitates formed in the near-surface layer for the Cr-free alloy. For both alloys, the precipitates have irregular shapes and are often elongated with lengths of 5-20 $\mu \mathrm{m}$ and widths of 0.5-1 $\mu \mathrm{m}$, and spaced $\sim 1 \mu \mathrm{m}$ apart, see Table 2 .

Figures 5 and 6 show the detailed microstructures of $\mathrm{Fe}_{28.2} \mathrm{Ni}_{18.8} \mathrm{Mn}_{32.9} \mathrm{Al}_{14.1} \mathrm{Cr}_{6}$ and $\mathrm{Fe}_{30} \mathrm{Ni}_{20} \mathrm{Mn}_{35} \mathrm{Al}_{15}$ after annealing at $1000^{\circ} \mathrm{C}$ for $100 \mathrm{~h}$ in nitrogen. Again, the center areas exhibited a two-phase lamellar microstructure, while AlN precipitates were found in the nearsurface layer, as confirmed by EDS result in Figure 5(c). Again, less than 1\% $\mathrm{Al}$ was left in the region where AlN formed. An ingot was cast of the matrix composition $\left(\mathrm{Fe}_{33.6} \mathrm{Ni}_{22.1} \mathrm{Mn}_{37.2} \mathrm{Al}_{0.6} \mathrm{Cr}_{6.6}\right)$ in the AlN-containing region of annealed $\mathrm{Fe}_{28.2} \mathrm{Ni}_{18.8} \mathrm{Mn}_{32.9} \mathrm{Al}_{14.1} \mathrm{Cr}_{6}$ and X-ray diffraction showed that it was single-phase f.c.c., see Figure 7. Compared to the needlelike AlN precipitates in the $800^{\circ} \mathrm{C}$ annealed alloys, the AlN precipitates in $1000^{\circ} \mathrm{C}$ 
annealed alloys were blocky and bigger. As at $800^{\circ} \mathrm{C}$, the $\mathrm{AlN}$ precipitates at $1000^{\circ} \mathrm{C}$ are irregularly shaped in both alloys. For the Cr-containing alloy, precipitates are up to $40 \mu \mathrm{m}$ long and 1-10 $\mu \mathrm{m}$ wide, and spaced $\sim 10 \mu \mathrm{m}$ apart. For the Cr-free alloy, the precipitates are larger at up to $60 \mu \mathrm{m}$ long and 2-10 $\mu \mathrm{m}$ wide, and spaced $\sim 20 \mu \mathrm{m}$ apart, see Table 2 . In contrast to the $800^{\circ} \mathrm{C}$ anneals, the lamellae structure in the center had coarsened somewhat after the $1000^{\circ} \mathrm{C}$ anneals to produce lamellae of size $~ 1.5 \mu \mathrm{m}$ for the f.c.c. phase and $~ 3.3 \mu \mathrm{m}$ for the B2 phase in the Cr-containing alloy, and $2.9 \mu \mathrm{m}$ for the f.c.c. phase and $\sim 2.3 \mu \mathrm{m}$ for the B2 phase in the CR-free alloy.

The Vickers hardness values of annealed materials from the center regions and the AlNcontaining areas are shown in Table 2. The hardness values of the as-cast materials are also shown in Table 2 for comparison, which are $261 \mathrm{HV}$ and $303 \mathrm{HV}$ for as-cast $\mathrm{Fe}_{28.2} \mathrm{Ni}_{18.8} \mathrm{Mn}_{32.9} \mathrm{Al}_{14.1} \mathrm{Cr}_{6}$ and as-cast $\mathrm{Fe}_{30} \mathrm{Ni}_{20} \mathrm{Mn}_{35} \mathrm{Al}_{15}$, respectively. The lower hardness in Cradded material is due to the softening of f.c.c. phase [15].

The areas containing AlN exhibit higher hardness than that of the center AlN-free areas in the same material, indicating the hardening of the surface by nitriding, see Table 2. For example, the hardness of $1000^{\circ} \mathrm{C}$ annealed $\mathrm{Fe}_{28.2} \mathrm{Ni}_{18.8} \mathrm{Mn}_{32.9} \mathrm{Al}_{14.1} \mathrm{Cr}_{6}$ is $234 \mathrm{HV}$ and $344 \mathrm{HV}$ for AlN-free and AlN-containing areas, respectively. The hardness of $800^{\circ} \mathrm{C}$ annealed materials show slightly higher values than the same materials annealed at $1000^{\circ} \mathrm{C}$. The hardness of $800^{\circ} \mathrm{C}$ annealed $\mathrm{Fe}_{28.2} \mathrm{Ni}_{18.8} \mathrm{Mn}_{32.9} \mathrm{Al}_{14.1} \mathrm{Cr}_{6}$ is $236 \mathrm{HV}$ and $364 \mathrm{HV}$ for AlN-free and AlN-containing areas, respectively. Kochmański et al. also found that the microhardness of the nitride layer in commercial 17-4 PH stainless steel depended mainly on the nitriding temperature and ranged from $900 \mathrm{HV}$ for temperatures about $570^{\circ} \mathrm{C}$ to $1700 \mathrm{HV}$ for temperatures lower than $500^{\circ} \mathrm{C}$ [4].

It is worth attempting to correlate the changes in microstructure with the changes in hardness. Meng et al. [30] showed that the yield strength $\sigma_{y}$ shows a linear relationship with the f.c.c. lamellae width $\lambda$ for lamellae FeNiMnAl alloys, i.e. $\sigma_{y}=252+0.00027 \lambda^{-1} \mathrm{MPa}$. Thus, the decrease of hardness in center lamellae-structured area compared to as-cast material is due to the observed coarsening of the phases. This coarsening is greater in the Cr-free material than in the Cr-added material (compare Figures 6a and 5a). Hence, the greater decrease in strength in the Cr-free alloy compared to the as-cast material.

The strength, $\sigma_{\mathrm{y}}$ in the nitrided areas can be described by strengthening from four mechanisms, i.e. 


$$
\sigma_{\mathrm{y}}=\sigma_{\mathrm{i}}+\sigma_{\mathrm{gb}}+\sigma_{\mathrm{ss}}+\sigma_{\mathrm{p}}
$$

where $\sigma_{\mathrm{i}}$ is the lattice friction, $\sigma_{\mathrm{gb}}$ is the grain boundary (Hall-Petch) strengthening, $\sigma_{\mathrm{ss}}$ is the solid solution strengthening, and $\sigma_{\mathrm{p}}$ is the strengthening due to particles. The grain boundary strengthening contribution in these alloys is likely to be small since grain sizes are $\sim 30-40 \mu \mathrm{m}$. The $\sigma_{\mathrm{i}}$ and $\sigma_{\mathrm{ss}}$ terms in equation (1) are unknown, but are likely to be slightly different since the matrix phase in the nitrided area contains only $\mathrm{Fe}, \mathrm{Ni}$ and $\mathrm{Mn}$ in the $\mathrm{Cr}$-free alloy, while the matrix in the Cr-containing alloy has $\mathrm{Fe}, \mathrm{Ni}, \mathrm{Mn}$ and $\mathrm{Cr}$. In a lattice where there are similar concentrations of each of the elements it is not possible to describe one of the elements as being a solute. Hence, separating the $\sigma_{\mathrm{i}}$ and $\sigma_{\mathrm{ss}}$ terms does not make a great deal of sense. The strengthening due the large precipitates observed in the nitrided areas will arise from dislocations bowing around the particles, and, hence, can be described by

$$
\sigma_{\mathrm{p}}=\mathbf{G b} / \mathbf{L}
$$

where $\mathbf{G}$ is the shear modulus, $\mathbf{b}$ is the Burgers' vector, and $\mathbf{L}$ is the spacing between particles. The values of $\mathbf{G}$ and $\mathbf{b}$ will be similar in both alloys. Comparing the hardness values and $\mathbf{L}$ values listed in Table 2, it appears that there is roughly a correlation between the hardness of the alloys and the reciprocal of the interparticle spacing irrespective whether the alloy contains $\mathrm{Cr}$ or not. Hence, the strength largely appears to derive from the interparticle spacing, which, as observed, depends on the nitriding temperature and the composition of the alloy. Presumably greater surface hardening could be obtained by nitriding at lower temperature - by using ammonia rather than nitrogen as the gaseous atmosphere - which would result in finer, more closely spaced AlN precipitates.

\section{Conclusions}

The as-cast HEA $\mathrm{Fe}_{28.2} \mathrm{Ni}_{18.8} \mathrm{Mn}_{32.9} \mathrm{Al}_{14.1} \mathrm{Cr}_{6}$ and $\mathrm{Fe}_{30} \mathrm{Ni}_{20} \mathrm{Mn}_{35} \mathrm{Al}_{15}$ were annealed in pure nitrogen at either $800^{\circ} \mathrm{C}$ or $1000^{\circ} \mathrm{C}$ for $100 \mathrm{~h}$, resulting in hardening of the surface due to the formation of AlN. Nitridation largely removed the $\mathrm{Al}$ from the matrix resulting in a single-phase f.c.c. matrix. Nitriding at lower temperatures and with $\mathrm{Cr}$ present resulting in greater hardening due to the formation of finer, more closely spaced AlN particles. The presence of $\mathrm{Cr}$ in the FeNiMnAl alloy led to an increased depth of the internal precipitation of AlN, i.e. to an increase 
in the diffusivity of $\mathrm{N}$, a feature noted previously in Ni-Cr-Ti alloys [9]. The diffusivities of $\mathrm{N}$ in both alloys were significantly lower than that in unalloyed f.c.c. iron.

\section{Acknowledgments}

This research was supported by U.S. Department of Energy (DOE), Office of Basic Energy Sciences grant DE-FG02-07ER46392. The views and conclusions contained herein are those of the authors and should not be interpreted as necessarily representing official policies, either expressed or implied of the DOE or the U.S. Government. We would like to thank Zhangwei Wang in Dartmouth College for performing X-ray diffraction. 


\section{References}

[1]. E.R. Booser, Tribology Data Handbook: An Excellent Friction, Lubrication, and Wear Resource. 2010: CRC Press.

[2]. F. Hoffmann and P. Mayr, Nitriding and nitrocarburizing. ASM International, ASM Handbook, 1992. 18: p. 878-883.

[3]. M.H. Biglari, C.M. Brakman, E.J. Mittemeijer, and S. Van Der Zwaag, The kinetics of the internal nitriding of Fe-2 at. pct Al alloy. Metallurgical and Materials Transactions A, 1995. 26(4): p. 765-776.

[4]. P. Kochmański and J. Nowacki, Activated gas nitriding of 17-4 PH stainless steel. Surface and Coatings Technology, 2006. 200(22-23): p. 6558-6562.

[5]. B.S. Mann and V. Arya, Abrasive and erosive wear characteristics of plasma nitriding and HVOF coatings: their application in hydro turbines. Wear, 2001. 249(5-6): p. 354360.

[6]. W.H. Huang, K.C. Chen, and J.L. He, A study on the cavitation resistance of ion-nitrided steel. Wear, 2002. 252(5-6): p. 459-466.

[7]. Z. Ke Song and H. Herman, Cavitation erosion of titanium and Ti-6A1-4V: Effects of nitriding. Wear, 1982. 80(1): p. 101-113.

[8]. P.C. Van Wiggen, H.C.F. Rozendaal, and E.J. Mittemeijer, The nitriding behaviour of iron-chromium-carbon alloys. Journal of Materials Science, 1985. 20(12): p. 4561-4582.

[9]. U. Krupp and H.J. Christ, Internal Nitridation of Nickel-Base Alloys. Part I. Behavior of Binary and Ternary Alloys of the Ni-Cr-Al-Ti System. Oxidation of Metals, 1999. 52(34): p. 277-298.

[10]. Y. Liao and I. Baker, Microstructure and room-temperature mechanical properties of $\mathrm{Fe}_{30} \mathrm{Ni}_{20} \mathrm{Mn}_{35} \mathrm{Al}_{15}$. Materials Characterization, 2008. 59(11): p. 1546-1549.

[11]. Y. Liao, F. Meng, and I. Baker, Environmental embrittlement of two-phase $\mathrm{Fe}_{30} \mathrm{Ni}_{20} \mathrm{Mn}_{35} \mathrm{Al}_{15}$. Intermetallics, 2011. 19(10): p. 1533-1537.

[12]. F. Meng, I. Baker, and P.R. Munroe, The effects of environment on the dry sliding wear of eutectic $\mathrm{Fe}_{30} \mathrm{Ni}_{20} \mathrm{Mn}_{35} \mathrm{Al}_{15}$. Journal of Materials Science, 2012. 47(12): p. 4827-4837.

[13]. X. Wu, F. Meng, I. Baker, H. Wu, and P.R. Munroe, An Overview of Dry Sliding Wear of Two-Phase FeNiMnAl Alloys. MRS Online Proceedings Library, 2013. 1516: p. 103-108.

[14]. F. Meng, S.F. Bauer, Y. Liao, and I. Baker, Concentration dependence of Cr for alleviating environmental embrittlement in Fe30Ni20Mn35Al15. Intermetallics, 2015. 56(0): p. 28-32.

[15]. F. Meng, J. Qiu, and I. Baker, The effects of chromium on the microstructure and tensile behavior of $\mathrm{Fe}_{30} \mathrm{Ni}_{20} \mathrm{Mn}_{35} \mathrm{Al}_{15}$. Materials Science and Engineering A, 2013. 586(0): p. 4552.

[16]. J.W. Yeh, S.K. Chen, S.J. Lin, J.Y. Gan, T.S. Chin, T.T. Shun, C.H. Tsau, and S.Y. Chang, Nanostructured High-Entropy Alloys with Multiple Principal Elements: Novel Alloy Design Concepts and Outcomes. Advanced Engineering Materials, 2004. 6(5): p. 299-303.

[17] W.-H. Wu, C-C. Yang and J.-W. Yeh, Industrial Development of High-Entropy Alloys, Ann. Chim. Sci. Mat. 2006. 31(6): p. 737-747.

[18] J.-W. Yeh, Reecent Progree in High-Entropy Alloys, Ann. Chim. Sci. Mat. 2006. 31(6): p. 633-648. 
[19] J.-W. Yeh, S.-K. Chen, S.-J. Lin, J.-Y. Gan, T.-S. Chin, T.-T. Shun, C.-H. Tsau and S.-Y. Chang, Nanostructured high entropy alloys with multiple principal elements: novel alloy design concepts and outcomes. Adv Eng Mater. 2004, 6: p299-303.

[20] J.-W. Yeh, Alloy design strategies on high-entropy alloys. J. Metals, 2013, 65: p1759_ 1771.

[21] D.B. Miracle, J.D. Miller, O.N. Senkov, C. Woodward, M.D. Uchic and J. Tiley, Exploration and Development of High Entropy Alloys for Structural Applications, Entropy, 2014, 16: p494-525.

[22] K.-Y. Tsai, M.-H. Tsai, M.-H. and J.-W. Yeh, Sluggish diffusion in Co-Cr-Fe-Mn-Ni high-entropy alloys, Acta Mater., 2013, 61: p4887-4897.

[23] O.N. Senkov, G.B. Wiks, J.M. Scott and D.B. Miracle, Mechanical properties of Nb25Mo25Ta25W25 and V20Nb20Mo20Ta20W20 refractory high entropy alloys, Intermetallics, 2011, 19: p698-706.

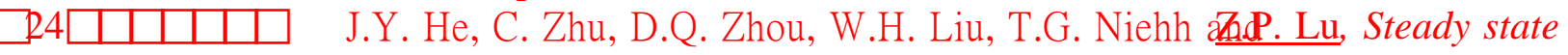
flow of the FeCoNiCrMn high entropy alloy at elevated temperatures, Intermetallics, 2014: 55: p 9-14.

[25] F. Otto, A. Dlouh'y, Ch. Somsen, H. Bei, G. Eggeler and E.P. George, The influences of temperature and microstructure on the tensile properties of a CoCrFeMnNi high-entropy alloy, Acta Mater., 2013, 61: p5743-5755.

[26] A. Gali and E. P. George, Tensile properties of high- and medium-entropy alloys, Intermetallics, 2013, 39: p74-78.

[27] B. Gludovatz, A. Hohenwarter, D. Catoor, E.H. Chang, E.P. George and R.O. Ritchie, A fracture-resistant high-entropy alloy for cryogenic applications, Science, 2014, 345(6201): p1153-1158.

[28]. U. Krupp and H.J. Christ, Internal Nitridation of Nickel-Base Alloys. Part II. Behavior of Quaternary Ni-Cr-Al-Ti Alloys and Computer-Based Description. Oxidation of Metals, 1999. 52(3-4): p. 299-320.

[29]. H. Jürgen Grabke and E. Marie Petersen, Diffusivity of nitrogen in iron-nickel alloys. Scripta Metallurgica, 1978. 12(12): p. 1111-1114.

[30]. F. Meng, J. Qiu, and I. Baker, Effect of Al content on the microstructure and mechanical behavior of two-phase FeNiMnAl alloys. Journal of Materials Science, 2014. 49(5): p. 1973-1983. 
Table 1. Compositions (in at. \%) of phases in as-cast $\mathrm{Fe}_{28.2} \mathrm{Ni}_{18.8} \mathrm{Mn}_{32.9} \mathrm{Al}_{14.1} \mathrm{Cr}_{6}$ and $\mathrm{Fe}_{30} \mathrm{Ni}_{20} \mathrm{Mn}_{35} \mathrm{Al}_{15}$, and after annealing at either $800^{\circ} \mathrm{C}$ or $1000^{\circ} \mathrm{C}$ for $100 \mathrm{~h}$ in pure nitrogen as determined from EDS measurements in a SEM. The values are the average of five measurements.

\begin{tabular}{|c|c|c|c|c|c|c|c|c|c|c|}
\hline U & 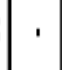 & & $\hat{b}$ & . & $\stackrel{\circ}{\circ}$ & . & & . & ' & ' \\
\hline ष &. & & r. & ' & $\stackrel{\circ}{\circ}$ & . & ' & ? & ' & n \\
\hline 离 &. & & $\stackrel{\text { f }}{\mathrm{f}}$ & ' & 굴 &. & & में & . & $\begin{array}{l}\infty \\
\stackrel{+}{+}\end{array}$ \\
\hline iz &. & & ते & ' & $\vec{i}$ & . & & $\stackrel{\circ}{\stackrel{9}{\leftrightarrows}}$ & ' & 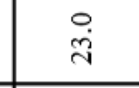 \\
\hline 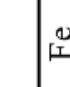 &. & & 일 & . & 户్లై & . & ' & $\vec{m}$ & ' & 宛 \\
\hline$z$ & 1 & & $\begin{array}{l}\stackrel{\infty}{\mathscr{f}} \\
\stackrel{f}{2}\end{array}$ & . & $\stackrel{\circ}{\stackrel{+}{+}}$ & . & ' & 号 & ' & $\begin{array}{l}\text { 多 } \\
\text { ra }\end{array}$ \\
\hline $\bar{\varangle}$ & . & & สี่ & . & 品 & . & ' & $\begin{array}{l}n \\
\dot{q} \\
\dot{q}\end{array}$ & . & 芦 \\
\hline b &  & 9 & & $\stackrel{m}{-}$ & ' & . & . & . & . & . \\
\hline $\bar{\sigma}$ & 空 & $\stackrel{n}{i}$ & & $\begin{array}{l}\infty \\
\text { ¿্ं } \\
\end{array}$ & . & $\begin{array}{l}\text { 일 } \\
\end{array}$ & में & ' & $\stackrel{n}{a}$ & 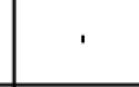 \\
\hline ตૈ & $\begin{array}{l}3 \\
0 \\
0\end{array}$ & $\stackrel{\text { D̊ }}{-1}$ & & $\overrightarrow{\mathrm{i}}$ & ' & 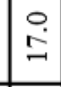 & ì & ' & : & . \\
\hline iz & $\stackrel{\circ}{\circ}$ & $\begin{array}{l}\vec{g} \\
\dot{m}\end{array}$ & ' & 品 & ' & 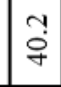 & $\stackrel{\stackrel{0}{\circ}}{\stackrel{m}{m}}$ & ' & $\stackrel{m}{g}$ & ' \\
\hline 0 & $?$ & $\stackrel{m}{m}$ & 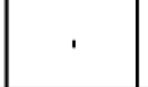 & 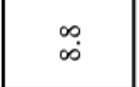 & . & \begin{tabular}{|l|}
$\infty$ \\
$\stackrel{0}{9}$
\end{tabular} & $\stackrel{\circ}{\dot{I}}$ & ' & $\stackrel{\circ}{\circ}$ & ' \\
\hline ن & $?$ & $\vec{\infty}$ & & $?$ & . & . &  & . & ' & ' \\
\hline $\bar{\varangle}$ & $\stackrel{\circ}{\circ}$ & $\vec{I}$ & & $\vec{\infty}$ & ' & $\begin{array}{ll}\infty \\
\stackrel{0}{0}\end{array}$ & $\stackrel{m}{\stackrel{9}{-}}$ & ' & $\vec{a}$ & ' \\
\hline 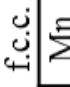 & $\stackrel{\vec{m}}{m}$ & $\begin{array}{l}n \\
0 \\
b \\
m\end{array}$ & & $\underset{m}{\stackrel{+}{m}}$ & . & \begin{tabular}{|l|}
$\stackrel{0}{0}$ \\
$\dot{m}$
\end{tabular} & $\stackrel{\infty}{\stackrel{\infty}{m}}$ & ' & वे & ' \\
\hline iz & $\stackrel{\vec{m}}{\rightarrow}$ & $\stackrel{\circ}{\circ}$ & & $\stackrel{n}{=}$ & . & 엄 & $\stackrel{\substack{3 \\
\infty \\
\rightarrow}}{-}$ & ' & $\stackrel{\circ}{\mathrm{g}}$ & 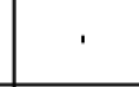 \\
\hline 番 & $\mid \begin{array}{c}\text { a } \\
\infty \\
\infty\end{array}$ & $\underset{\infty}{+\infty}$ & & 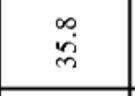 & ' & $\frac{7}{7}$ & ले & ' & $\begin{array}{c}\text { o } \\
\text { m } \\
\end{array}$ & \\
\hline $\begin{array}{l}\text { : } \\
\text { : } \\
\text { 。 } \\
0\end{array}$ &  & 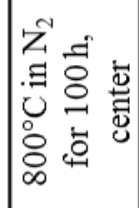 &  & 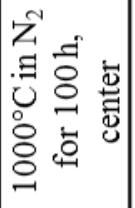 & 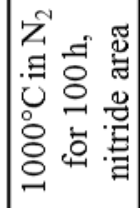 &  & 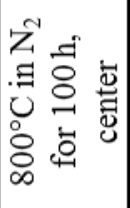 & 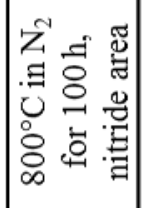 & 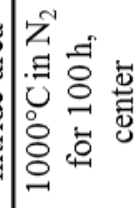 & 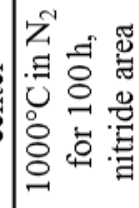 \\
\hline 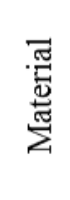 & & & 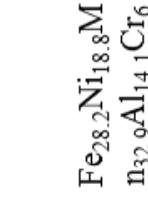 & & & & & 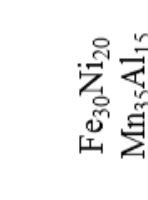 & & \\
\hline
\end{tabular}


Table 2. Hardness of $\mathrm{Fe}_{28.2} \mathrm{Ni}_{18.8} \mathrm{Mn}_{32.9} \mathrm{Al}_{14.1} \mathrm{Cr}_{6}$ and $\mathrm{Fe}_{30} \mathrm{Ni}_{20} \mathrm{Mn}_{35} \mathrm{Al}_{15}$ in both the as-cast condition and after annealing at either $800^{\circ} \mathrm{C}$ or $1000^{\circ} \mathrm{C}$ for $100 \mathrm{~h}$ in pure nitrogen, and the interparticle spacing of the AlN precipitates, $\mathrm{L}$, in the nitrided areas.

\begin{tabular}{|c|c|c|c|c|}
\hline Material & Condition & $\begin{array}{c}\text { Center } \\
(\mathrm{HV})\end{array}$ & $\begin{array}{c}\text { Nitrided } \\
\text { area (HV) }\end{array}$ & $\begin{array}{c}\text { L ( } \mu \text { m) } \\
\text { AlN ppts }\end{array}$ \\
\hline \multirow{3}{*}{$\mathrm{Fe}_{28.2} \mathrm{Ni}_{18.8} \mathrm{Mn}_{32.9} \mathrm{Al}_{14.1} \mathrm{Cr}_{6}$} & As cast & $261 \pm 9$ & - & 10 \\
\cline { 2 - 5 } & $\begin{array}{c}1000^{\circ} \mathrm{C} \text { in } \\
\mathrm{N}_{2} \text { for } 100 \mathrm{~h}\end{array}$ & $234 \pm 5$ & $344 \pm 18$ & 1 \\
\cline { 2 - 5 } & $\begin{array}{c}800^{\circ} \mathrm{C} \text { in } \mathrm{N}_{2} \\
\text { for } 100 \mathrm{~h}\end{array}$ & $236 \pm 5$ & $364 \pm 8$ & 20 \\
\hline \multirow{3}{*}{$\mathrm{Fe}_{30} \mathrm{Ni}_{20} \mathrm{Mn}_{35} \mathrm{Al}_{15}$} & As cast & $303 \pm 5$ & - & $269 \pm 12$ \\
\cline { 2 - 5 } & $\begin{array}{c}1000^{\circ} \mathrm{C} \text { in } \\
\mathrm{N}_{2} \text { for } 100 \mathrm{~h}\end{array}$ & $206 \pm 6$ & 269 \\
\cline { 2 - 5 } & $\begin{array}{c}800^{\circ} \mathrm{C} \text { in } \mathrm{N}_{2} \\
\text { for } 100 \mathrm{~h}\end{array}$ & $215 \pm 3$ & $343 \pm 15$ & 1.5 \\
\hline
\end{tabular}




\section{Figure Captions:}

Figure 1. SE images of (a) as-cast $\mathrm{Fe}_{28.2} \mathrm{Ni}_{18.8} \mathrm{Mn}_{32.9} \mathrm{Al}_{14.1} \mathrm{Cr}_{6}$ and (b) as-cast $\mathrm{Fe}_{30} \mathrm{Ni}_{20} \mathrm{Mn}_{35} \mathrm{Al}_{15}$. The microstructure consists of f.c.c.(dark) and $\mathrm{B} 2$ (light) phases.

Figure 2. BSE images of (a) and (b) $\mathrm{Fe}_{28.2} \mathrm{Ni}_{18.8} \mathrm{Mn}_{32.9} \mathrm{Al}_{14.1} \mathrm{Cr}_{6}$ after annealing for $100 \mathrm{~h}$ in nitrogen at $800^{\circ} \mathrm{C}$ and $1000^{\circ} \mathrm{C}$, respectively; (c) and (d) $\mathrm{Fe}_{30} \mathrm{Ni}_{20} \mathrm{Mn}_{35} \mathrm{Al}_{15}$ after annealing for $100 \mathrm{~h}$ in nitrogen at $800^{\circ} \mathrm{C}$ and $1000^{\circ} \mathrm{C}$, respectively. The black features are $\mathrm{A} 1 \mathrm{~N}$ precipitates.

Figure 3. BSE images of $\mathrm{Fe}_{28.2} \mathrm{Ni}_{18.8} \mathrm{Mn}_{32.9} \mathrm{Al}_{14.1} \mathrm{Cr}_{6}$ after annealing at $800^{\circ} \mathrm{C}$ for $100 \mathrm{~h}$ in nitrogen: (a) in the center of the specimen remaining lamellar two-phase structure and (b) near the surface where AlN (black features) formed; (c and d) X-ray spectra from the dark precipitates and light matrix, respectively.

Figure 4. BSE images of $\mathrm{Fe}_{30} \mathrm{Ni}_{20} \mathrm{Mn}_{35} \mathrm{Al}_{15}$ after annealing at $800^{\circ} \mathrm{C}$ for $100 \mathrm{~h}$ in nitrogen: (a) in the center of the specimen the lamellar two-phase structure remains and (b) near the surface where AlN (black features) formed.

Figure 5. BSE images of $\mathrm{Fe}_{28.2} \mathrm{Ni}_{18.8} \mathrm{Mn}_{32.9} \mathrm{Al}_{14.1} \mathrm{Cr}_{6}$ after annealing at $1000^{\circ} \mathrm{C}$ for $100 \mathrm{~h}$ in nitrogen: (a) in the center of the specimen remaining lamellar two-phase structure and (b) near the surface with AlN precipitates; (c and d) X-ray spectra from the dark precipitates and light matrix, respectively.

Figure 6. SE images of $\mathrm{Fe}_{30} \mathrm{Ni}_{20} \mathrm{Mn}_{35} \mathrm{Al}_{15}$ after annealing at $1000^{\circ} \mathrm{C}$ for $100 \mathrm{~h}$ in nitrogen: (a) in the center of the specimen remaining lamellar two-phase structure and (b) near the surface with black AlN precipitates.

Figure 7. XRD pattern from bulk as-cast $\mathrm{Fe}_{35.7} \mathrm{Ni}_{23.0} \mathrm{Mn}_{40.8} \mathrm{Al}_{0.5}$, showing that it is single phase f.c.c. 

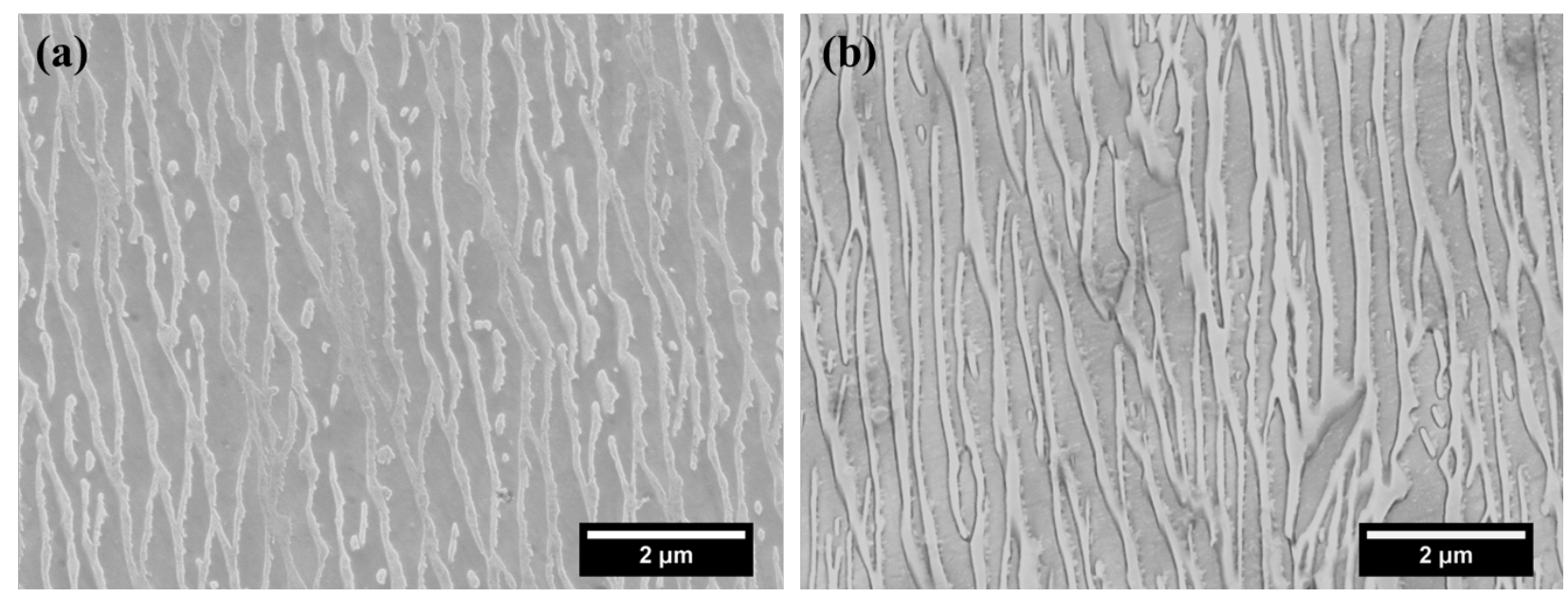

Figure 1. SE images of (a) as-cast $\mathrm{Fe}_{28.2} \mathrm{Ni}_{18.8} \mathrm{Mn}_{32.9} \mathrm{Al}_{14.1} \mathrm{Cr}_{6}$ and (b) as-cast $\mathrm{Fe}_{30} \mathrm{Ni}_{20} \mathrm{Mn}_{35} \mathrm{Al}_{15}$. The microstructure consists of f.c.c.(dark) and B2 (light) phases. 

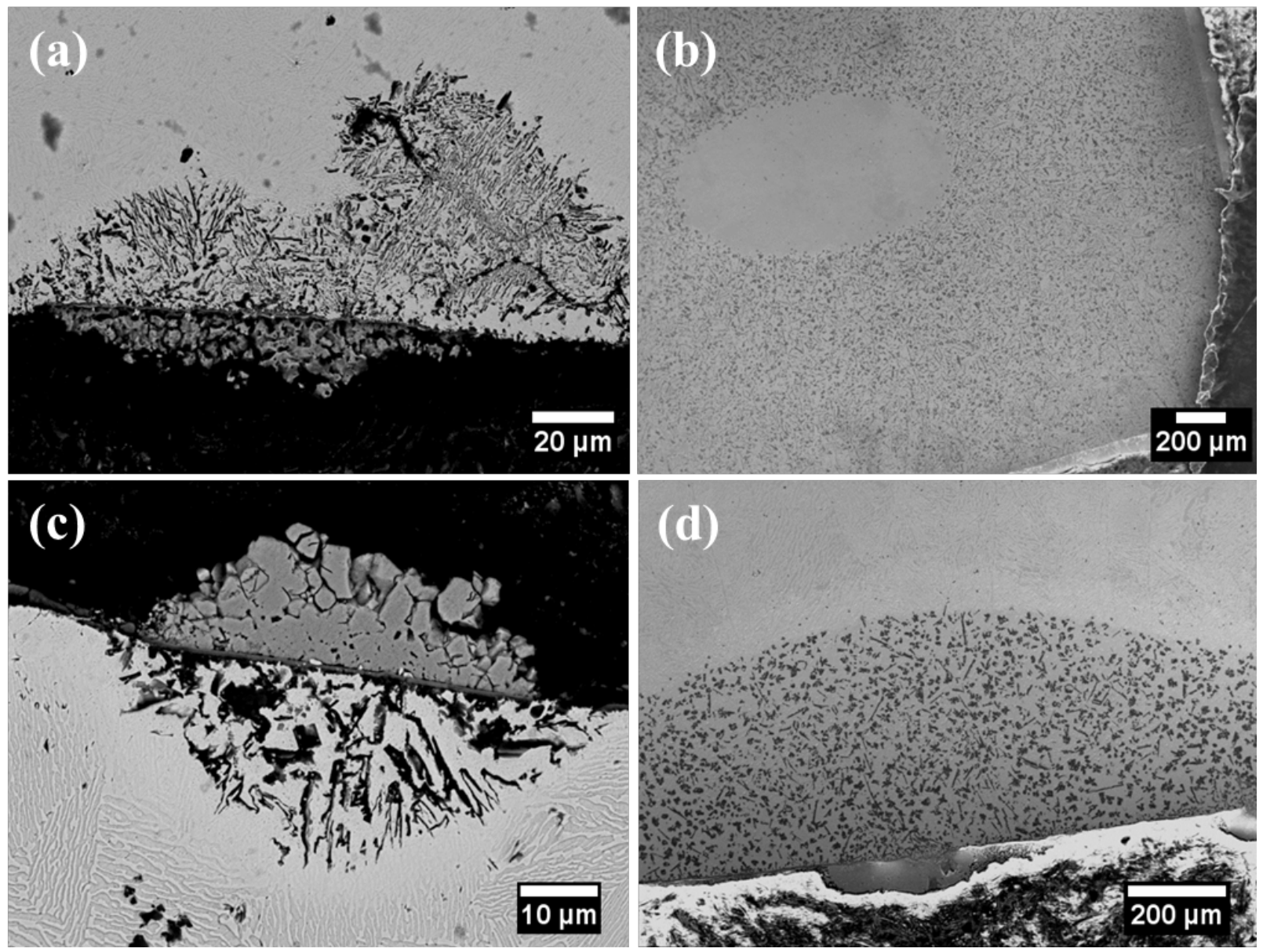

Figure 2. BSE images of (a) and (b) $\mathrm{Fe}_{28.2} \mathrm{Ni}_{18.8} \mathrm{Mn}_{32.9} \mathrm{Al}_{14.1} \mathrm{Cr}_{6}$ after annealing for $100 \mathrm{~h}$ in nitrogen at $800^{\circ} \mathrm{C}$ and $1000^{\circ} \mathrm{C}$, respectively; (c) and (d) $\mathrm{Fe}_{30} \mathrm{Ni}_{20} \mathrm{Mn}_{35} \mathrm{Al}_{15}$ after annealing for $100 \mathrm{~h}$ in nitrogen at $800^{\circ} \mathrm{C}$ and $1000^{\circ} \mathrm{C}$, respectively. The black features are A1N precipitates. 



Figure 3. BSE images of $\mathrm{Fe}_{28.2} \mathrm{Ni}_{18.8} \mathrm{Mn}_{32.9} \mathrm{Al}_{14.1} \mathrm{Cr}_{6}$ after annealing at $800^{\circ} \mathrm{C}$ for $100 \mathrm{~h}$ in nitrogen: (a) in the center of the specimen remaining lamellar two-phase structure and (b) near the surface where AlN (black features) formed; (c and d) X-ray spectra from the dark precipitates

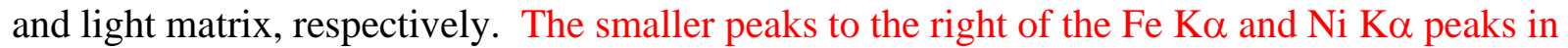
(d) are the corresponding $\mathrm{K} \beta$ peaks. 




Figure 4. BSE images of $\mathrm{Fe}_{30} \mathrm{Ni}_{20} \mathrm{Mn}_{35} \mathrm{Al}_{15}$ after annealing at $800^{\circ} \mathrm{C}$ for $100 \mathrm{~h}$ in nitrogen: (a) in the center of the specimen the lamellar two-phase structure remains and (b) near the surface where AlN (black features) formed. 

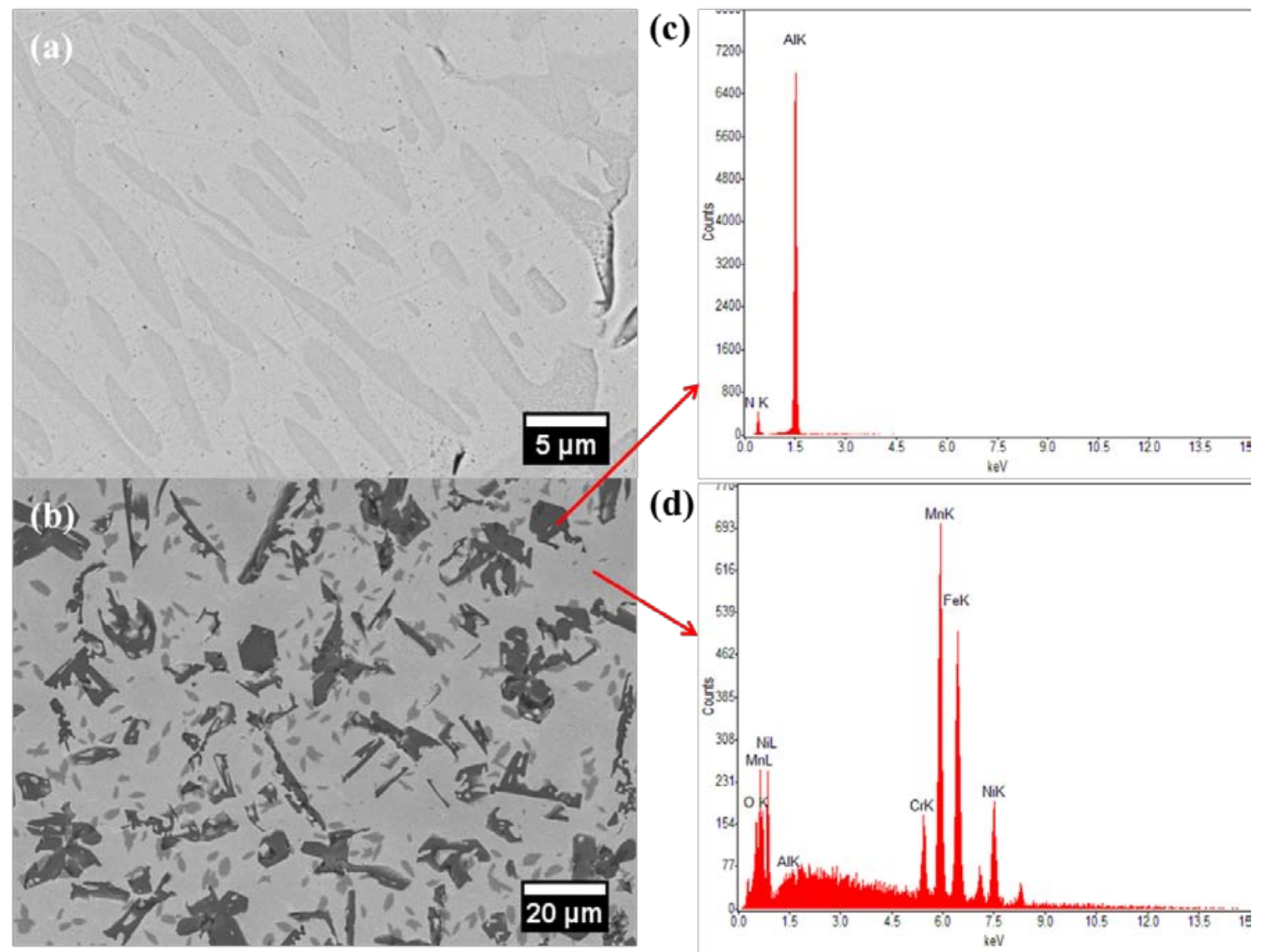

Figure 5. BSE images of $\mathrm{Fe}_{28.2} \mathrm{Ni}_{18.8} \mathrm{Mn}_{32.9} \mathrm{Al}_{14.1} \mathrm{Cr}_{6}$ after annealing at $1000^{\circ} \mathrm{C}$ for $100 \mathrm{~h}$ in nitrogen: (a) in the center of the specimen remaining lamellar two-phase structure and (b) near the surface with AlN precipitates; (c and d) X-ray spectra from the dark precipitates and light matrix, respectively. The smaller peaks to the right of the Fe $\mathrm{K} \alpha$ and Ni K $\alpha$ peaks in (d) are the corresponding $\mathrm{K} \beta$ peaks. 


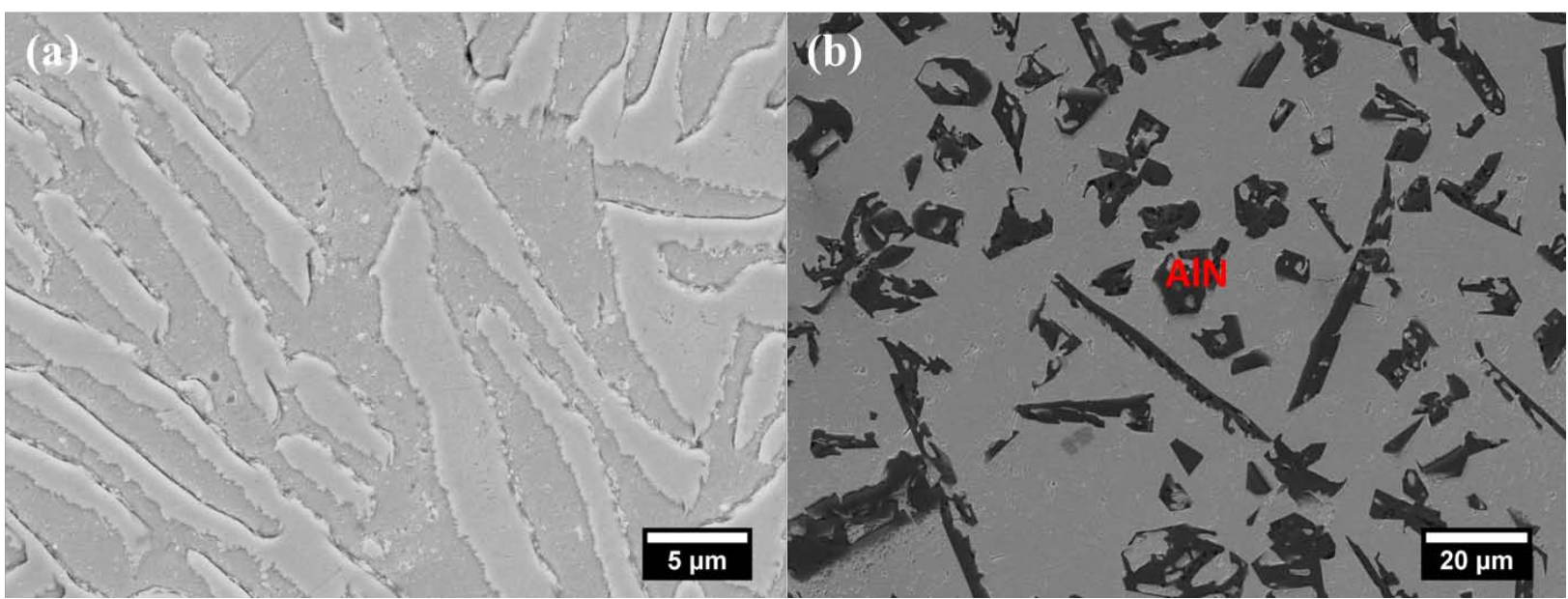

Figure 6. SE images of $\mathrm{Fe}_{30} \mathrm{Ni}_{20} \mathrm{Mn}_{35} \mathrm{Al}_{15}$ after annealing at $1000^{\circ} \mathrm{C}$ for $100 \mathrm{~h}$ in nitrogen: (a) in the center of the specimen remaining lamellar two-phase structure and (b) near the surface with black AlN precipitates. 


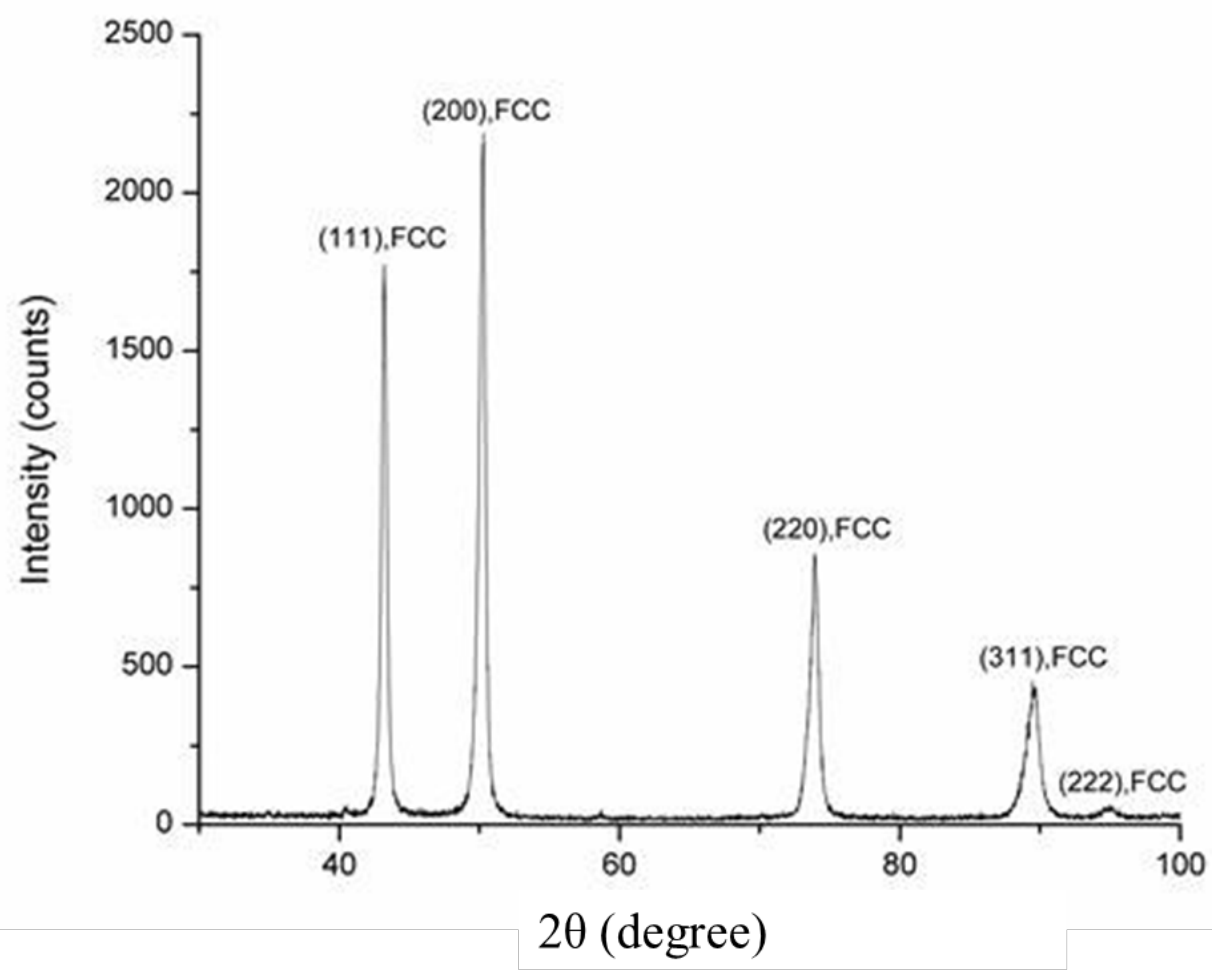

Figure 7 . XRD pattern from bulk as-cast $\mathrm{Fe}_{35.7} \mathrm{Ni}_{23.0} \mathrm{Mn}_{40.8} \mathrm{Al}_{0.5}$, showing that it is single phase f.c.c. 